“İ̧,,Güç” Endüstri İlişkileri ve Insan Kaynakları Dergisi

Cilt:10 Sayı:1 , Ocak 2008, ISSN: 1303-2860

“İs, Güç" The Journal of Industrial Relations and Human Resources

Vol:10 No:1 January 2008, ISSN: 1303-2860

\title{
LIDERLIK VE TOPLAM KALITE YÖNETIMININ ALGILANMA BOYUTU: ÜNIVERSITE ÖĞRENCILERI ÜZERINE BIR ARAŞTIRMA
}

\author{
CELALETTIN SERINKAN \\ Yard.Doç.Dr.Pamukkale Üniversitesi, İiBF
}

\begin{abstract}
This paper is based on a study conducted for the purpose of determining the attitudes of students on the subjects of transformational leadership, passive leadership and total quality management. To accomplish this, first factor analyses were conducted on all the variables of the tools and the variables with sufficient factor weights were determined. Then cluster analysis was conducted to gather the students into meaningful groups. In addition relationships were looked for between dimensions that had been determined.

Research data and information were collected from a convenience sample of 290 third and fourth year students of Istanbul University Faculty of Business Administration using questionnaires.
\end{abstract}

Key words: Transformational Leadership, Passive Leadership, Total Quality Management 


\section{ÖZET}

Bu çalışmada, öğrencilerin dönüşümcü liderlik, pasif liderlik ve toplam kalite yönetimi konularındaki algılamaları belirlenmeye çalışılmıştır. Bunun için ilk önce ölçekler faktör analizine tabi tutulmuş ve faktör yükleri yeterli olan değişkenler belirlenmiştir. Daha sonra öğrencilerin anlamlı gruplar altında toplanmaları için kümeleme analizi yapılmıştır. Ayrıca belirlenen boyutlar arasındaki ilişkilere bakılmıştır.

Araştırmanın veri ve bilgileri, I.Ü. İşletme fakültesi örgün öğretim lisans öğrencileri arasından üçüncü ve dördüncü sınıflardaki öğrencilerden toplanmıştır. Veri ve bilgilerin toplanmasında tesadüfi örnekleme yöntemi kullanılmış olup, geçerli olan 290 anket analiz sürecine dâhil edilmiştir.

Anahtar Kelimeler: Dönüşümcü Liderlik, Pasif Liderlik, Toplam Kalite Yönetimi

\section{GíRiş}

Değişimlerin sürekli devam ettiği günümüz ortamında kişilerin her zaman yeniliklere ve dönüşümlere hazır halde olmaları ve rekabetten kopmamaları için yeniliklere uyum sağlamaları gerekmektedir. İşletmeler için rekabette ve kurumsallaşmada gerekli olan yönetim anlayışlarından birisi de toplam kalite yönetimi felsefesine sahip olmadır. Bu anlayışa sahip olan kişiler pek çok dönüşümleri gerçekleştirebilirler.

Meydana gelen dönüşümler aynı zamanda işletme okullarında okuyan öğrencileri de etkilemektedir. Çünkü öğrenciler de kendilerini mezuniyetten sonraki iş yaşamına hazırlanırken kendilerini en iyi şekilde yetiştirmek zorundadırlar. Bu nedenle öğrencilerin değişime ve dönüşüme açık olmaları beklenir. Çalışma hayatında önemli bir yeri olan toplam kalite anlayışı, aynı zamanda bir yaşam felsefesi olduğu için öğrencilerin mükemmele ulaşmalarında toplam kalite yaklaşımının da önemli bir yeri vardır. Etkileşimci liderliğin üçüncü boyutu olan ve değişimlere kapalı, mevcutla yetinmeyi öngören pasif liderlik eğiliminde olan öğrencilerin toplam kalite felsefesine sahip olmaları ve dönüşümleri gerçekleştirmeleri pek olası değildir. Bu çalışmada öğrencilerin dönüşümcü ve etkileşimci liderliğe nasıl baktıkları ve bu liderlerin özelliklerine ilişkin düşünceleri öğrenilmeye çalışılmıştır.

Dönüşümcü liderlik ve etkileşimci liderlik kavramları 1985 yılından sonra Burns ve Bass'ın çalışmalarından sonra tartışmaya açılmış ve ülkemizde de özellikle 1990'dan sonra bu konularda araştırmalar yapılmaya başlanmıştır (Bass ve Avolio, 1999, 430, Akdemir, 1997, 67). Bu çalışmada da dönüşümcü liderlik, pasif liderlik ve toplam kalite yönetimi konularında İstanbul Üniversitesi, İşletme 
Fakültesi öğrencilerinin algılamaları belirlenmeye çalışılmıştır. Bu fakültede öğrenim gören öğrenciler, aynı zamanda liderlik ve toplam kalite yönetimi dersleri görmektedirler. Bu çalışmada ayrıca ölçeklerden elde edilecek faktör analizi sonucunda oluşacak boyutların korelasyonları değerlendirilecektir. Bunların yanısıra dönüşümcü liderlik, toplam kalite yönetimi ve pasif liderlik ölçekleri arasındaki ilişkiler araştırılacaktır.

\section{KURAMSAL TEMEL}

Dönüşümcü liderlik konusundaki araştırmalar özellikle 1990'ı yıllardan itibaren büyük artış göstermeye başlamıştır. Dönüşümcü liderliğin boyutları genel olarak üç boyut altında toplandığını araştırmacılar belirtmektedirler (Stephen, 1995, 27-28; Bass ve Avolio, 1999, 441). Bunlar;

1- Karizmatik Liderlik: Karizma, neyin gerçekten önemli olduğunu anlamak ve misyon duygusunu başkalarına aşılamaktır. Bu tür liderlik özelliğine sahip olan kişiler, organizasyondaki bütün çalışanları etkiler.

2- Bireysel İlgi: Transformasyonel liderlik kavramı liderlerin bireyler üzerine eğilmesini, onları desteklemeyi, koç tipi (coaching) liderlik sergileyerek onlara hizmet etmeyi, yetki devrini gerçekleştirmek için bir öğretmen gibi bireyleri eğitmeyi ve eğitim imkânlarından yararlandırmayı gerektirir.

3- Zihinsel Teşvik: Liderlerin zihnî becerileri iyi kullandığı bilinmektedir. Bu kabiliyetlerinin iyi olması nedeniyle izleyenlerini cesaretlendirebilir ve problemlere yeni bir bakış açısı getirebilirler. Mevcut fikirleri yeniden düşünerek bunların çözümü için problem çözme tekniklerinin kullanırlar.

Dönüşümcü liderlikle beraber araştırılan etkileşimci liderlik konusunda yapılan teorik çalışmalarda genel olarak kabul edilen üç boyutun olduğudur (Lakomski, 2001).

1. Şarta Bağlı Ödül: Liderin izleyicilerin hedeflere ve amaçlara ulaştıklarında ödül vermesidir. İstenilen konuya ulaşmak için lider ve takipçileri arasında pozitif pekiştirme vardır. İşyerinde çalışanlar işlerini ödül almak ve görevlerini yerine getirmiş olmak için yaparlar. Yöneticilerle astlar arasında şartı bir pazarlık söz konusudur.

2. İstisnalarla Yönetim- Aktif: işletmede bir hatanın ortaya çıkmaması için performans sonuçlarını izlemeyi ve bir problemin düzeltilmesi gerekmesi halinde liderlerin harekete geçmesini ifade etmektedir. Bu harekete geçme negatif geri bildirim verme, cezalandırma veya disipline verme olarak olabilir. 
3. Pasif Liderlik (İstisnalarla Yönetim-Pasif): Burada yöneticiler, çalışanlarını tamamen serbest bırakmış durumdadır. Liderler gerekli kararları almakta zorlanmalarının yanısıra zaman zaman kararlar ertelenir. Problemlerin düzeltilmesi için müdahale söz konusu değildir. Yani herkesin yaptıkları işlerde ve yerine getirdikleri görevlerde serbest bırakılması, onlara pek karışılmamasını ifade eder. Bu anlayış, problemlerin çözümünü astlardan bekleme davranışıdır. Ancak problem iyice büyür ve kaçınılmaz bir hale geldikten sonra çözmek için uğraşılır. Diğer bir değişle yangın büyüdükten sonra müdahale etmektir.

Dönüşümcü liderlik konusunda ülkemizde de çalışmalar yapılmıştır. Bunlardan bazıları aşağıda özetlenmektedir.

Dönüşümcü liderlik, etkileşimci liderlik ve performans konusunda Uyguç ve arkadaşlarının Dokuz Eylül Üniversitesine bağlı fakülte ve yüksek okullarda öğrenim gören 539 öğrenciye yönelik yaptıkları araştırmada; öğretim üyelerinin dönüşümcü liderlik ve etkileşimci liderlik davranışlarının ders türüne göre farklılaştığı fakat öğrencilerin okudukları sınıf açısından farklılaşmadığı ileri sürülmektedir. Ayrıca bu çalışmada öğrencilerin cinsiyetine göre kız öğrencilerin ortalamaları karizma, bireysel ilgi, koşulsal ödül ve istisnalarla yönetim boyutları ortalamaları erkek öğrencilere göre daha yüksek bulunmuştur. Yine bu araştırmada; dönüşümcü liderliğin belirleyici özelliği olan karizmatik liderlik ve entelektüel teşvik boyutlarının sayısal derslerde, algılanan öğretim üyesi performansındaki değişimlerin \%69'unu açıkladığı; sözel ve uygulamalı derslerde ise öğretim üyesinin algılanan performansını açıklayan tek bağımsız değişkenin karizmatik liderlik boyutu olduğu bulunmuştur (Uyguç, Duygulu ve Çıraklar, 2000, 587-600).

Dönüşümcü liderlik tarzının işletmelerde uygulanabilmesi için köklü değişimlere intiyaç bulunmaktadır. Toplam kalite yönetimini bir örgütte uygulama için de köklü değişimlerin gerçekleştirilmesine gerek vardır. Toplam kalite yönetiminin işletmelerde uygulanabilmesi için Deming'in ilkelerini göz önünde bulundurmak gerekmektedir. (Giaver, 2001). Deming'in toplam kalite yönetimi ilkeleri bütün dünyada kabul görmüş ilkelerdir. Bu ilkeler şunlardır: (Serinkan, 2003, 151)

Uzun Döneme Odaklanma, Yeni Felsefenin Benimsenmesi, Girdi Kontrolünden Vazgeçilmesi, Kaliteye Önem Verilmesi, Süreç Geliştirilmesi, İşbaşında Eğitim Sistemi, Liderliğin Benimsenmesi, Korkunun Yok Edilmesi, Bölümler Arası İşbirliğinin Sağlanması, Slogan ve Posterlere Bağlanmamak, Sayısal Hedeflere Odaklanmaktan Kaçınmak, İstatistik Eğitiminin Verilmesi, Eğitim Programlarının Düzenlenmesi, Katılımının Sağlanması. 
Toplam kalite yönetimi işletmeler için büyük öneme sahiptir. İleride işletmelerin değişik kademelerinde çalışacak olan öğrencilerin toplam kalite anlayışına sahip olarak mezun olmaları gerekmektedir.

\section{GEREÇ VE YÖNTEM}

Bu çalışmada dönüşümcü liderlik, toplam kalite yönetimi ve pasif liderlik kavramları ile ilgili olarak işletme fakültesin öğrencilerinin tutumları belirlenmeye çalışılmıştır. Ayrıca öğrencilerin farklı düşüncelere sahip olacakları düşüncesiyle bahsedilen konularda öğrencilerin farklı kümelerde yer alacakları düşüncesiyle analizler yapılmıştır.

\section{1. Ölçüm Aracı ve Değişkenler}

Araştırmada iki ölçek kullanılmıştır. Bunlardan birisi dönüşümcü liderlik ve pasif liderlik ölçeği, diğeri de toplam kalite yönetimi bilinci ölçeğidir. Dönüşümcü liderlik ve pasif liderlik ölçeğinin hazırlanmasında Bernard Bass ve Bruce Avolio'nun test ettiği MLQ-5 ölçeğinden (Bass ve Avolio, 1999, 441) ve Hartog, Muijen ve Jaap'ın önerdikleri ölçekten yararlanılmıştır (Hartog, Muien ve Jaap, 1997, 19). Dönüşümcü liderlik ve pasif liderlik ölçeğinde 29 ifade bulunmaktadır. Bu ölçeğin öğrencilere uygulanacak olması nedeniyle ifadeler şu şekilde oluşturulmuştur. Örnek: dönüşümcü liderler; çalışanlar tarafından benimsenmiş ortak misyonu vurgularlar, ahlâkî değerlere özen gösterirler, genellikle hevesli ve coşkulu konuşurlar. Böylelikle öğrencilerin dönüşümcü liderlerin nasıl olması gerektiğini belirtmiş olacaklardır. Pasif liderlik ve toplam kalite yönetimi ölçeklerinin ifadeleri de aynı şekilde hazırlanmıştır. Bu sayede öğrencilerin belirtilen konulara karşı algılamaları ve tutumları belirlenmiş olacaktır.

Anketin ikinci ölçeği ise yöneticilerin toplam kalite yönetimi bilincini ölçmeye yönelik olarak hazırlanmıştır. Bunun için de toplam kalite yönetimi konusunda uzman olan Deming'in ondört ilkeden oluşan toplam kalite yönetimini uygulama ilkelerinden yararlanılmıştır. Bu ilkelerin her biri birer boyut olarak düşünülmüş ve ölçek soruları oluşturulmuştur. Toplam kalite yönetimi bilinci ölçeğinde 30 ifade bulunmaktadır.

\subsection{Ana Kütle ve Örneklem}

Çalışmanın an kütlesi, İstanbul üniversitesi İşletme fakültesinde öğrenim gören üçüncü ve dördüncü sınıf öğrencilerdir. Veri ve bilgilerin toplanmasında tesadüfi örnekleme yöntemi kullanılmış olup, geçerli cevap alınan toplam 290 anket değerlendirmeye alınmıştır. 
Cevaplayıcıların 206'sı Türkçe öğretim, 84'ü de İngilizce öğretim programına dâhildir. Türkçe programına kayıtlı öğrencilerin 97 si gündüz, 109'u ise gece eğitimine kayıtlıdır. Ankete cevap veren 290 öğrencinin 158 öğrenci $(\% 54,5)$ üçüncü sınıfta ve 132 öğrenci $(\% 45,5)$ ise dördüncü sınıf öğrencisidir.

\subsection{Uygulanan İstatistiksel Analizler}

Araştırmaların ölçümlerinin güvenilir olup olmadıklarını ölçen Crombach alpha güvenilirlik analizi bütün araştırmalar için gerekli olan bir analizdir. Bu araştırmanın dönüşümcü liderlik için güvenilirlik katsayısı Crombach alpha değeri ,87 olarak tespit edilmiştir. Toplam kalite yönetimi ölçeğinin güvenirliği ise ,88 dir.

Anket formu aracılığı ile toplanan verilerin düzenlenmesi ve analizlerin yapılması için "SPSS 11.0 for Windows" istatistik paket programı kullanılmıştır. Araştırmada kümeleme analizi (Cluster Analysis) kullanımıştır. Ayrıca değişkenlerin birbirleri ile ilişkilerini belirleyen korelasyon analizi (Orhunbilge, 2002, 25) kullanılmıştır. Bağımsız değişkenlerin hangilerinin bağımlı değişkeni ne kadar açıkladıklarını belirlemek üzere de regresyon analizi kullanılmıştır. Regresyon analizi, bağımlı değişkendeki değişimin ne kadarının bağımsız değişkenler tarafından açıklandığını belirlemek için yapılır (Akgül ve Çelik, 2003, 297).

\section{BULGULAR VE TARTIŞMA}

Bu kısımda ilk önce araştırmanın güvenilirlik bilgileri verilmekte ve elde edilen faktör analizi sonuçları değerlendirilmektedir. Daha sonraki kısımlarda da kullanılan diğer analiz bulgularına yer verilmektedir.

\subsection{Boyutlara İlişkin Güvenirlik Analizi ve Faktör Analizi Bulguları}

Yapılan faktör analizi sonucuna göre oluşan dönüşümcü liderlik ölçeğinin boyutları karizma, zihinsel teşvik ve bireye odaklanma olarak belirlenmiştir. Toplam kalite yönetimi ölçeğinde ise yapılan faktör analizi sonucu boyutlar üç boyut altında toplanmış ve bunlar yönetimin kararlılığı, süreç iyileştirme ve ekip yönetimi olarak oluşmuştur. Boyutlara ilişkin güvenirlilikler aşağıda gösterilmektedir. 
Tablo 1: Boyutlara İlişkin Güvenirlik Oranları

\begin{tabular}{lc}
\hline \hline Boyutlar & Güvenirlik $(\alpha)$ \\
\hline Dönüşümcü Liderlik &, 87 \\
Karizma &, 72 \\
Zihinsel Teşvik &, 71 \\
Bireye Odaklanma &, 72 \\
Toplam Kalite Yönetimi &, 88 \\
Yönetimin Kararlılığı &, 74 \\
Süreç İileştirme &, 74 \\
Ekip Yönetimi &, 73 \\
Pasif Liderlik &, 76 \\
\hline
\end{tabular}

Dönüşümcü liderlik ve pasif liderliğe ilişkin 29 ifade, toplam kalite yönetimine ilişkin 30 ifade faktör analizine tabi tutulmuştur. Toplam kalite yönetimi ilkeleri başlıca faktör analizi sonucunda üç boyut altında toplanmıştır. Faktör yüklemelerinin tespitinde varimax düzeltme yöntemi kullanılmıştır. Faktör kümelerine ilişkin sonuçlar aşağıdaki tablo 2' de gösterilmektedir.

Tablo 2: Dönümcü Liderliğe İlişkin Faktör Yüklemeleri

\begin{tabular}{lllccc}
\hline \hline \multicolumn{2}{c}{ Karizma } & \multicolumn{2}{c}{ Zihinsel Teşvik } & \multicolumn{2}{c}{ Bireye Odaklanma } \\
\hline V1 &, 504 & V12 &, 807 & V3 &, 708 \\
V2 &, 653 & V13 &, 750 & V4 &, 744 \\
V17 &, 703 & V14 &, 745 & V9 &, 760 \\
V18 &, 631 & V19 &, 619 & V11 &, 652 \\
V22 &, 699 & & & & \\
\multicolumn{2}{c}{ V23 } &, 698 & & &
\end{tabular}

Açıklanan toplam varyans: 51,410

Kaiser-Meyer-Olkin ve Barlett testleri modelin uygunluğunu ve belirlenen faktörlerin gerçekten birbirinden bağımsız olup olmadıklarını test etmektedir. KMO değerinin ,50 ile 1 arasında olması arzulanmaktadır (Ordun, 2002, 135). Karizma boyutuna ilişkin KMO değeri ,77 ve Barlett Ki-Kare değeri 308,13 olarak bulunmuş ve anlamlılık değeri ise ,00 olarak tespit edilmiştir. Zihinsel teşvik boyutu KMO değeri ,73 Barlett Ki-Kare 213,05, anlamlılık ,00 dir. Bireye odaklanma boyutuna ilişkin KMO değeri ,69 ve Barlett Ki-Kare değeri 184,28 anlamlılık ise ,00 olarak bulunmuştur. Bu değer, alt faktörlerin 
gerçekten birbirlerinden farklı konuları ölçmekte olduğunu ifade etmektedir. Pasif liderliğe ilişkin analiz sonuçları aşağıda gösterilmektedir.

Tablo 3: Pasif Liderliğe İlişkin Faktör Analizleri

\begin{tabular}{cc}
\hline \hline & Pasif Liderlik \\
\hline V5 &, 642 \\
V8 &, 678 \\
V10 &, 679 \\
V15 &, 669 \\
V26 &, 662 \\
V29 &, 715 \\
\hline
\end{tabular}

Açıklanan toplam varyans :45,480

Pasif liderlik boyutunda KMO değeri ,77 olarak belirlenmiştir. Barlett testine göre Ki-Kare değeri 369,32 ve anlamlılık değeri ise ,00 olarak tespit edilmiştir. Bu değerler pasif liderlikle ilgili alt faktörlerin gerçekten birbirlerinden farklı konuları ölçmekte olduğunu ifade etmektedir. Toplam kalite yönetimine ilişkin faktör yüklemeleri aşağıda belirtilmektedir.

Tablo 4: Toplam Kalite Yönetiminin Boyutlarına İlişkin Faktör Yüklemeleri

\begin{tabular}{cccccc}
\hline \multicolumn{2}{c}{ Yönetimin Kararlıı̆ı̆ı } & \multicolumn{2}{c}{ Süreç l̇yileştirme } & \multicolumn{2}{c}{ Ekip Yönetimi } \\
\hline B1 &, 648 & B5 &, 711 & B6 &, 618 \\
B2 &, 798 & B7 &, 637 & B8 &, 565 \\
B3 &, 818 & B11 &, 639 & B15 &, 576 \\
B4 &, 740 & B12 &, 597 & B16 &, 582 \\
& & B13 &, 678 & B19 &, 602 \\
& & B14 &, 689 & B22 &, 615 \\
& & & B23 &, 653 \\
& & & B27 &, 622 \\
\hline
\end{tabular}

Açıklanan toplan varyans : 56,868

Toplam kalite yönetiminin değişkenlerine ilişkin yapılan faktör analizi sonucunda üç boyut oluşmuş ve bu boyutlara ilişkin ifadeler toplam kalite yönetimini ölçmektedir. Yönetimin kararlılığına ilişkin KMO değeri ,75 ve Barlett Ki-Kare değeri 261,31 ve anlamlılık değeri ,00 olarak bulunmuştur. Süreç iyileştirme boyutunun KMO değeri ,79 ve Barlett KiKare değeri 319,79 ve anlamlılık ,00 olarak belirlenmiştir. 


\subsection{Araştırmanın Kümeleme Analizi Bulguları}

Öğrencilerin dönüşümcü liderlik ve toplam kalite yönetimine göre anlamlı gruplara ayırabilmek için Kümeleme Analizi (K-Means Cluster) kullanılmıştır. Kümeleme analizi; (kişiler, ürünler, bölgeler, vb.) kavramların sahip oldukları karakteristik özelliklerini temel alarak gruplandıran çok değişkenli bir analiz yöntemidir (Şekerkaya ve Yüksel, 2002, 17).

Cevaplayıcıların dönüşümcü liderlik, pasif liderlik ve toplam kalite yönetimine ilişkin tutumlarının farklı olacağını belirlemek için her ölçek için ayrı ayrı kümeleme analizleri yapılmıştır. Kümeleme analizi uygulanırken 3'lü küme oluşturulmuş ve anlamlı olanlar belirlenmiştir.

\subsubsection{Dönüşümcü Liderliğe İlişkin Kümeleme Analizi Bulguları}

Dönüşümcü liderliğe ilişkin yapılan kümeleme analizi sonucunda birinci kümede 128, ikinci kümede 29 ve üçüncü kümede 133 kişi bulunmaktadır. Dönüşümcü liderlik ölçeğine ilişkin öğrencilerin genel tutumlarına varyans analizi uygulanmıştır. 14 değişkenlik bataryamıza \%95 güven sınırlarında uygulanan analiz sonuçlarına göre yine 14 değişken ilgili güven sınırlarının üzerinde kalmış ve anlamlı farklılıkların olduğu tespit edilmiştir.

Tablo 5: Dönüşümcü Liderliğe İlişkin Nihai Küme Merkezleri

Anl. Dönüşümcü Liderlik İfadeleri

1.Küme $\begin{array}{cc}2 . & 3 . \\ \text { Küme Küme }\end{array}$

,000Misyonu vurgulamak (V1)

$3,58 \quad 2,59 \quad 4,10$

,000Ahlaki değerlere özen göstermek (V2)

3,65

2,62

4,15

,000Eğitim ve rehberlik (V3)

3,80

2,52

4,41

,000Güven vermek (V4)

3,66

2,24

4,63

,000Yetenekleri ortaya çıkarmak (V9)

3,36

2,34

4,41

,000Güçlü yanlara odaklanmak (V11)

3,60

3,14

4,34

,000Tüm intimalleri düşünmek (V12)

3,74

2,55

4,51

,000Yeni yollar önermek (V13)

3,75

2,76

4,29

,000Sorunların bilincinde olmak (V14)

3,61

2,76

4,42

,000Saygı duyulmak (V17)

3,74

2,59

4,41

,000lyimser olmak (V18)

3,59

2,52

3,79

4,00

,000Farklı görüşleri ortaya çıkarmak (V19)

3,65

2,55

4,17

,000Hataların nedenlerini araştırmak (V22)

3,66

2,52

4,41

,000Hataların takip etmek (V23)

$2,69 \quad 4,33$


Kümeleme analizi sonucunda dönüşümcü liderlik ifadelerine katıımları açısından katılımcılar üç kümede toplanmaktadır. İkinci kümede toplanan 29 öğrencinin dönüşümcü liderlik konusunda tutumlarının ortalamaları düşüktür. Bu gruptaki cevaplayıcıların dönüşümcü liderlikle ilgili bilgileri azdır. Birinci kümede toplanan 128 kişinin dönüşümcü liderlik bilgilerinin düzeyi ortadır. Başka bir değişle bu kümedeki kişilerin dönüşümcü liderlik ifadelerine katılımları yeterli düzeydedir. Dönüşümcü liderlik bilincine sahip olan küme üçüncü kümedir. Çünkü bu kümedeki katılımcıların dönüşümcü liderlik ifadelerine katılımları genel olarak yüksektir. Bu haliyle üçüncü kümedeki 133 öğrencinin dönüşümcü liderlik bilincine sahip oldukları söylenebilir.

\subsubsection{Toplam Kalite Yönetimine İlişkin Kümeleme Analizi Bulguları}

Toplam kalite yönetimine ilişkin yapılan faktör analizi sonucunda 30 ifadeden 18 ifade kümeleme analizine tabi tutulmuş ve ifadelerin hepsi anlamlı olarak bulunmuştur. Birinci kümede 142, ikinci kümede 38 ve üçüncü kümede de 110 kişi bulunmaktadır.

\section{Tablo 6: Toplam Kalite Yönetimine İlişkin Nihai Küme Merkezleri}

\begin{tabular}{|c|c|c|c|c|}
\hline $\begin{array}{l}\text { Anlam- } \\
\text { lılık }\end{array}$ & Toplam Kalite Yönetimi İfadeleri & 1.Küme & $\begin{array}{c}2 . \\
\text { Küme }\end{array}$ & $\begin{array}{c}3 . \\
\text { Küme }\end{array}$ \\
\hline ,000 & Uzun döneme odaklanma (B1) & 3,74 & 2,66 & 4,22 \\
\hline ,000 & İşletme amaçlarını belirleme (B2) & 3,80 & 2,84 & 4,47 \\
\hline, 000 & Yenilikçi davranış gösterme (B3) & 4,01 & 2,61 & 4,67 \\
\hline ,000 & Vizyonun ve misyonun paylaşımı (B4) & 3,95 & 3,08 & 4,75 \\
\hline ,000 & Sistem kurma (B5) & 3,83 & 3,05 & 4,54 \\
\hline ,000 & Toplam kalite yönetiminin yararı (B6) & 3,81 & 3,13 & 4,49 \\
\hline ,000 & Ürün ve hizmetlerin geliştirilmesi (B7) & 3,85 & 2,89 & 4,69 \\
\hline ,000 & Kıyaslama yapmak (B8) & 3,49 & 3,61 & 4,22 \\
\hline ,000 & Çabaları desteklemek (B11) & 3,80 & 3,39 & 4,54 \\
\hline, 000 & İstatistik tekniklerinden yararlanmak (B12) & 3,75 & 2,61 & 4,15 \\
\hline ,000 & İşbaşı eğitiminin verilmesi(B13) & 3,82 & 2,79 & 4,30 \\
\hline ,000 & Eğitim araçlarından yararlandırma (B14) & 3,70 & 3,11 & 4,45 \\
\hline 000 & İstatistik eğitiminin yararı (B15) & 3,55 & 2,95 & 4,08 \\
\hline ,000 & Sürekli eğitim (B16) & 3,72 & 2,87 & 4,31 \\
\hline ,000 & Liderlerin çalışanlara güvenmeleri (B19) & 3,76 & 3,26 & 4,34 \\
\hline ,000 & Bölümler arası iletişim (B22) & 3,74 & 3,03 & 4,48 \\
\hline ,000 & Ekiplere istekli katılım (B23) & 3,73 & 3,11 & 4,45 \\
\hline, 000 & Öneri sistemi (B27) & 3,70 & 2,87 & 4,35 \\
\hline
\end{tabular}

Toplam kalite yönetimi değişkenlerine yönelik yapılan kümeleme analizi sonucunda öğrenciler üç kümeye ayrılmaktadır. İkinci kümede 
yer alan 38 öğrencinin toplam kalite yönetimi bilinçleri düşüktür. Birinci kümedeki öğrencilerin toplam kalite yönetimi bilinçleri orta düzeyde ve üçüncü kümedeki kişilerin bilinçleri yüksek düzeydedir. Birinci kümede 142 kişi yer alırken üçüncü kümede 110 kişi yer almaktadır. Genel olarak öğrencilerin toplam kalite yönetimi felsefesine sahip oldukları söylenebilir.

\subsubsection{Pasif Liderliğe İlişkin Kümeleme Analizi Bulguları}

Pasif liderlik ölçeğinde yer alan 6 değişkene ilişkin yapılan kümeleme analizinde cevaplayıcılar üç kümede toplanmış ve kümelerle arasında farklar anlamlı olarak bulunmuştur. Bu analiz sonucunda birinci kümede 68, ikinci kümede 78 ve üçüncü kümede 144 kişi yer almıştır. Pasif liderlik ifadelerinde numaralandırma (1:kesinlikle katılmıyorum, 5: kesinlikle katııyorum) şeklindedir.

\section{Tablo 7: Pasif Liderliğe Iliş̧in Nihai Küme Merkezleri}

\begin{tabular}{lccc} 
Anl. Pasif Liderlik İfadeleri & 1.Küme & $\begin{array}{c}\text { 2. } \\
\text { Küme }\end{array}$ & 3. Küme \\
\hline ,000 Karar vermekten kaçınma (V5) & 3,00 & 2,83 & 1,43 \\
,000 Sorun çözmekten kaçınma (V8) & 2,62 & 2,88 & 1,40 \\
,000 Süreçleri geliştirmeme (V10) & 3,24 & 3,58 & 1,90 \\
,000 Sorunun kronikleşmesi (V15) & 3,15 & 3,28 & 1,85 \\
,000 Önlem almamak (V26) & 2,65 & 3,88 & 1,97 \\
,000 İşlerin kontrolden çıkması (V29) & 1,84 & 4,04 & 1,66 \\
\hline
\end{tabular}

Pasif liderlik değişkenleri açısından kümeler farklı tutum sergilemişlerdir. Liderlerin karar vermekten kaçınmaları konusunda birinci ve ikinci kümedeki öğrenciler kararsız kalırken üçüncü kümedekiler bu ifadeye katılmamaktadırlar.

Diğer ifadeler açısından da birinci ve ikinci kümedeki öğrenciler genel olarak kararsız kalmalarına rağmen üçüncü kümedeki öğrenciler bu ifadelere katılmadıklarını belirtmişlerdir. Bu durumda sadece üçüncü kümedeki cevaplayıcılar pasif liderliğe karşı olumsuz tutum sergilemişlerdir. Bu nedenle sadece üçüncü kümedeki öğrenciler pasif liderliği benimsememektedirler.

\subsection{Değişkenler Arası Korelasyon Bulguları}

Dönüşümcü liderlik boyutları ile toplam kalite yönetiminin boyutları arasında ve de pasif liderlik arasında yapılan korelasyon değerlerini gösteren tablo aşağıda gösterilmektedir. 
Tablo 8: Değişkenler Arası Korelasyon Bulguları

(1) (2) (3) (4)

(5) (6) (7) (8)
(1) Karizma
(2) Zihinsel Teşvik
(3) Bireye Odaklanma
(4) Dönüşümcü Liderlik
(5) Yönetimin Kararlıı̆̆ı
(6) Süreç İyileştirme
(7) Ekip Yönetimi
(8) TKY
(9) Pasif Liderlik
Pearson 1
Sig

Pearson, 627
Sig, 000

Pearson ,674, 623

Sig. ,000, 000

Pearson ,868

Sig. , 000

Pearson ,563

Sig. , 000

Pearson ,646

Sig. , 000

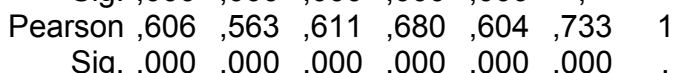

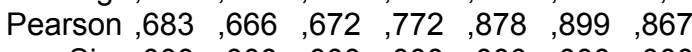

Sig. ,000, 000, 000, 000, 000, 000, 000

Pearson,- 456

Sig. , 000

Korelasyonlar 0,01 düzeyinde anlamlıdır (Çift Yönlü).

Yapılan çift yönlü korelasyon analizi sonucuna göre değişkenler arasında \%99 güven aralığında güçlü ve anlamlı ilişkiler vardır. Sadece pasif liderlik ile diğer değişkenler arasındaki korelasyonlar negatiftir ve değişkenler arasındaki ilişkiler anlamlıdır. Diğer bir ifadeyle pasif liderlik ile dönüşümcü liderlik ve boyutları arasında negatif bir ilişki vardır. Dönüşümcü liderlik ile pasif liderlik birbirinin zıddıdır. Aynı şekilde pasif liderlik ile toplam kalite yönetimi ve boyutları arasında negatif ilişkiler sözkonusudur. Toplam kalite yönetimi ile pasif liderlik arasında olumsuz anlamda ilişki sözkonusudur.

Dönüşümcü liderlik ile toplam kalite yönetimi arasındaki ilişkiye bakıldığında, $(r=0,77 \quad p=0,01)$ iki değişken arasındaki ilişkinin güçlü olduğu görülmektedir. Dönüşümcü liderliğin boyutları ile toplam kalite yönetiminin boyutları arasında da güçlü ilişkilerin olduğu görülmektedir (tablo 8). Çünkü karizma, zihinsel teşvik, bireye odaklanma, yönetimin kararlığı, süreç iyileştirme ve ekip yönetimi arasında güçlü ilişkiler bulunmaktadır. Ayrıca bu boyutların dönüşümcü liderlik ve toplam kalite yönetimi arasında da güçlü ilişkiler vardır.

\subsection{Dönüşümcü Liderlik Boyutları İle Toplam Kalite Yönetimi Regresyon Bulguları}

Dönüşümcü liderliğin boyutları olan karizma, zihinsel teşvik ve bireye odaklanma bağımsız değişkenler olarak alınıp bağımlı değişken 
olan toplam kalite yönetimi üzerinde ne kadarlık bir etkiye sahip olduklarını belirlemek amacıyla regresyon analizi yapılmıştır. Diğer bir ifadeyle toplam kaliteyi dönüşümcü liderliğin boyutlarının ne kadar açıkladığına bakmak için adım adım regresyon (stepwise regression) analizi yapılmıştır.

Tablo 9: Toplam Kalite Yönetimine İlişkin Regresyon Bulguları

\begin{tabular}{|c|c|c|c|c|c|}
\hline & \multicolumn{2}{|c|}{ Katsayılar } & \multirow{2}{*}{$\begin{array}{c}\text { Standardize Katsayılar } \\
\text { Beta }\end{array}$} & \multirow[t]{2}{*}{$\mathrm{t}$} & \multirow[t]{2}{*}{ Anl. } \\
\hline & B & $\begin{array}{l}\text { Std. } \\
\text { Hata }\end{array}$ & & & \\
\hline (Constant) & 1,227 & 134 & & 9,167 & ,000 \\
\hline KARIZMA & ,265 & ,047 & ,308 & 5,659 & ,000 \\
\hline ZIHINSEL TEŞVIK & 230 & ,040 & 299 & 5,813 & ,000 \\
\hline BİREYE ODAKLANMA & ,203 & ,040 & ,278 & 5,133 &, 000 \\
\hline Düzeltilmiş R Kare &, 593 & & & & \\
\hline
\end{tabular}

a Bağımlı Değişken: TOPLAM KALITE YÖNETIMI

Dönüşümcü liderlik boyutlarının toplam kalite yönetimi üzerindeki etkisine ilişkin yapılan regresyon sonucunda anlamlı sonuçlara ulaşılmıştır $(p=, 00)$. $R$ değeri, 77 ve $R$ kare değeri ise ,597 olarak tespit edilmiştir. Düzeltilmiş $R^{2}$ değeri ise, 593 olarak bulunmuştur.

Toplam kalite yönetimini dönüşümcü liderliğin boyutlarının ne kadarını açıkladığını gösteren formülü (Toplam Kalite Yönetimi $=1,227$ ,+ 27 Karizma + ,23 Zihinsel Teşvik + ,20 Bireye Odaklanma) şeklinde yazılabilir. Standardize katsayılar incelendiğinde karizma değişkeninin ,31 ve zihinsel teşvik değişkeninin ,30 ve de bireye odaklanma değişkeninin ,28 düzeyinde etkide bulunduğu anlaşılmaktadır.

\section{SONUÇ}

Araştırmadan elde edilen bulgulara göre aşağıdaki sonuçlara göre öğrenciler dönüşümcü liderlik konusunda yeterli bilgiye sahiptirler. Yapılan kümeleme analizine göre öğrencilerin büyük çoğunluğu bu konudaki ifadelere katılmaktadırlar. Toplam kalite yönetimi açısından öğrencilerin eğilimleri de genel olarak yüksektir.

Pasif liderlik yönünden birinci ve ikinci kümedeki öğrenciler kararsız kalmışlardır. Bunların sayısı araştırmaya katılan öğrencilerin yarısını oluşturmaktadır. Üçüncü kümede yer alan 144 öğrenci ise pasif liderlik ifadelerine katılmamaktadırlar.

Dönüşümcü liderlikle toplam kalite yönetimi arasında güçlü bir ilişki söz konusudur. Karizma, zihinsel teşvik ve bireye odaklanmayla toplam kalite yönetimi arasında da güçlü ilişkiler vardır. Toplam kalite 
yönetiminin boyutları olan yönetimin kararlılığı, süreç iyileştirme ve ekip yönetimiyle dönüşümcü liderlik arasında güçlü ilişkiler tespit edilmiştir. Yine toplam kalite yönetiminin boyutlarıyla dönüşümcü liderliğin boyutları arasında güçlü ve anlamlı korelasyonlar bulunmaktadır.

Pasif liderlikle dönüşümcü liderlik ve toplam kalite yönetimi arasında negatif ilişkiler söz konusudur. Ayrıca karizma, zihinsel teşvik, bireye odaklanma, yönetimin kararlılığı, süreç iyileştirme ve ekip yönetimiyle de pasif liderli arasında olumsuz korelasyonlar vardır. Toplam kalite yönetiminin açıklanmasında dönüşümcü liderliğin birinci boyutu olan karizmanın oldukça önemli bir rolü bulunmaktadır. Ayrıca zihinsel teşvik ve bireye odaklanma değişkenlerinin de toplam kalite yönetimi üzerinde önemli derecede etkileri söz konusudur.

$\mathrm{Bu}$ araştırmadan elde edilen sonuçlar göstermektedir ki toplam kalite yönetimini uygulamak için köklü değişikliklerin yapılması ve bunun sağlanabilmesi için de dönüşümcü liderlik özelliklerine sahip olmak gerekmektedir. Toplam kalite yönetimi felsefesinin yerleştirebilmesi için insan unsuruna büyük önem vermek ve onları her yönden teşvik etmek, istekli şekilde katılımı sağlamak önem arzetmektedir. Bununla beraber geleceğin çalışanları olacak olan öğrencilerin her zaman için yeniliklere ve değişimlere açık bireyler olarak yetiştirilmeleri ve toplam kalite anlayışına sahip bireyler olarak yetiştirilmelerinin yararı ortadadır. 
KAYNAKLAR

Akdemir Ali, "21. Yüzyılda Dönüşümler ve Dönüştürücü Liderlik Profili”, 21. Yüzyılda Liderlik Sempozyumu, İstanbul, 1997, s. 67.

Akgül Aziz, Osman Çelik, İstatistiksel Analiz Teknikleri:SPSS'te İşletme

Yönetimi Uygulamaları, Ankara, Emek Ofset, 2003, s. 297.

Bass, Bernard M., Bruce J. Avolio: "Re-Examining The Component Of Transformational And Transactional Leadership Questionnaire", Journal of Occupational \& Organizational Pschology, Vol. 72, Issue 4, Aralık 1999, s. 441.

Giaever Henrik, "Does Total Quality Management Restrain Innovation", (Çevrimiçi) www.giaever.com/does_total_quality_management_re.html, 09.04.203.

Hartog N. Deanne, Van Muijen, J. Jaap, "Transactional Versus Transformational Leadership: An Analysis Of The MLQ", Journal of Occupational and Organizational Psychology, Mart 1997, Vol. 70, Issue 1, s. 19.

Lakomski Gabriele, "Leadership and Learning: From Transformational Leadership to Organizational Learning", (Çevrimiçi), www.unimelb.edu.tr.au/david_gurr/482-707/lakomski_95.html, 20.6.2001.

Orhunbilge Neyran, Uygulamalı Regresyon ve Korelasyon Analizi, 2.b., İstanbul, i.Ü. İşletme Fak. Yayın No: 281, 2002, s. 25.

Serinkan, Celalettin, Toplam Kalite Yönetimi IIle Dönüşümcü Liderlik İlişkisi ve Denizli Yöresinde Yapılan Bir Araştırma, Yayınlanmamış Doktora Tezi, İstanbul Üniversitesi, Sosyal Bilimler Enstitüsü, 2003, s. 151.

Stephen George, Arnold Weimerskirch, Total Quality Management, John Wiley \& Sons Inc., 1995, s. 27-28.

Şekerkaya Ahmet, Cenk Arsun Yüksel, "Tüketicilerin Internete Karşı Tutumlarına Göre Kümeler Halinde Incelenmesi”, i.Ü.Işletme Fakültesi Dergisi, C:31, S:2, Kasım 2002, s. 17

Uyguç Nermin, Ethem Duygulu, Nurcan Çıraklar, "Dönüşümcü Liderlik, Etkileşimci Liderlik ve Performans", 8. Ulusal Yönetim ve Organizasyon Kongresi, Nevşehir, 2000, s. 587-600 